\title{
Respiratory viral infections in pediatric patients with hematopoietic stem cell transplantation
}

\author{
José F. Gaytán-Morales ${ }^{1}$, Iván Castorena-Villa1 , Dolores C. Cortés-Flores ${ }^{1}$, Martha J. Avilés-Robles², \\ José L. Sánchez-Huerta ${ }^{3}$, Vianney Ortiz-Navarrete ${ }^{4}$, Irlanda Olvera-Gómez ${ }^{5,6}$, Briceida López-Martínez7, \\ and Israel Parra-Ortega ${ }^{3 *}$
}

\begin{abstract}
'Servicio de Trasplante de Médula Ósea, Hospital Infantil de México Federico Gómez, Mexico City; ${ }^{2}$ Departamento de Infectología Pediátrica, Hospital Infantil de México Federico Gómez, Mexico City; ${ }^{3}$ Departamento de Laboratorio Clínico, Hospital Infantil de México Federico Gómez, Mexico City; ${ }^{4}$ Centro de Investigación y Estudios Avanzados, Instituto Politécnico Nacional, Mexico City; ${ }^{5}$ Hospitales Federales de Referencia, Hospital Nacional Homeopático, Mexico City; ${ }^{6}$ Universidad Anáhuac Norte, Naucalpan de Juárez, State of Mexico; ${ }^{7}$ Subdirección de Servicios Auxiliares de Diagnóstico, Mexico City. Mexico
\end{abstract}

\begin{abstract}
Background: Viral respiratory infections in pediatric patients with hematopoietic stem cell transplantation (HSCT) significantIy impact morbidity and mortality. It is necessary to determine the viral agents and their frequency of presentation to understand their impact on transplantation patients' evolution. Methods: From January 2017 to December 2019, we conducted a cross-sectional, descriptive, and observational study of patients who underwent HSCT with a viral respiratory infection. Viral identification was performed using multiplex polymerase chain reaction for nine respiratory viruses. Descriptive statistics were performed with a report of central tendency measures and percentages. Results: Of the 54 pediatric patients who underwent HSCT, 59.2\% presented an airway infection; in turn, at least one viral agent was identified in $59.3 \%$ of these patients. The most frequent viral agents were influenza (25.9\%), human rhinovirus (18.5\%), and respiratory syncytial virus (18.5\%). Viral co-infections occurred in $36.8 \%$ of the cases. The reported complications were supplemental oxygen requirement (73.6\%), support with mechanical ventilation (21\%), admission to the pediatric intensive care unit (15.7\%), and mortality associated with a viral respiratory infection (10.5\%). Conclusions: Viral respiratory infections are frequent in pediatric patients with HSCT; influenza $A / B$ virus was the most frequent agent. As morbidity and mortality increase due to these infections in patients with HSCT, strategies are necessary for its prevention and timely treatment after transplantation.
\end{abstract}

Key words: Stem cell transplantation. Respiratory tract infections. Respiratory virus.

\section{Infecciones respiratorias virales en pacientes pediátricos con trasplante de células progenitoras hematopoyéticas}

\section{Resumen}

Introducción: Las infecciones respiratorias virales en los pacientes pediátricos con trasplante de células progenitoras hematopoyéticas (TCPH) impactan significativamente la morbilidad y la mortalidad. Para comprender su impacto en la evolución de los pacientes receptores de trasplantes es necesario conocer la frecuencia de presentación y los agentes virales.

\section{Correspondence:}

*Israel Parra Ortega

E-mail: i_parra29@hotmail.com
Date of reception: 08-05-2020

Date of acceptance: 03-09-2020

DOI: 10.24875/BMHIM.20000126
Available online: 08-06-2021

Bol Med Hosp Infant Mex. 2021;78(3):191-199

www.bmhim.com 1665-1146/@ 2020 Hospital Infantil de México Federico Gómez. Published by Permanyer. This is an open access article under the CC BY-NC-ND license (http://creativecommons.org/licenses/by-nc-nd/4.0/). 
Métodos: De enero de 2017 a diciembre de 2019 se llevó a cabo un estudio transversal, descriptivo y observacional de los pacientes sometidos a TCPH que tuvieron una infección viral de vías respiratorias. La identificación de los virus se realizó por medio de la prueba de reacción en cadena de la polimerasa multiplex para nueve virus respiratorios. Se realizó estadística descriptiva con reporte de medidas de tendencia central y porcentajes. Resultados: De los 54 pacientes incluidos, el $59.2 \%$ presentaron una infección de vías respiratorias y se identificó al menos un agente viral en el $59.3 \%$ de estos casos. Los virus más frecuentes fueron influenza (25.9\%), rinovirus humano (18.5\%) y virus sincitial respiratorio (18.5\%). En el 36.8\% de los casos se detectaron coinfecciones virales. Se presentaron las siguientes complicaciones: requerimiento de oxígeno suplementario (73.6\%), soporte con ventilación mecánica (21\%), ingreso a la unidad de cuidados intensivos pediátricos (15.7\%) y muerte asociada a infección por virus respiratorios (10.5\%). Conclusiones: Las infecciones respiratorias virales en los pacientes pediátricos con TCPH son frecuentes; el virus influenza A/B es el agente más habitual. Debido a que estas infecciones se asocian con mayor morbimortalidad en los pacientes con TCPH, son estrategias necesarias para su prevención y tratamiento oportuno posterior al trasplante.

Palabras clave: Trasplante de médula ósea. Infecciones de vías respiratorias. Virus respiratorio.

\section{Introduction}

Hematopoietic stem cell transplantation (HSCT) is a curative treatment for multiple hematologic and non-hematologic pathologies in pediatric patients. One of HSCT's objectives is reconstituting the hematopoietic system, including the immune system. Post-transplant immune reconstitution begins with the recovery of the innate immune response (natural killer [NK] cells, neutrophils, monocytes, dendritic cells, and $\mathrm{T}$ cells) from 15 days to 2 months after transplant. The adaptive immune response (CD4+ T cells and B cells) has a later recovery, occurring up to 24 months after transplantation ${ }^{1}$. During viral infections, macrophages and NK cells belong to the innate immune system and are part of the first defense barrier. Toll-like receptors recognize pathogen ligands, such as nucleic acids, and lead to the production of type I interferons (IFN- $\alpha$ and IFN- $\beta$ ), which will limit the infection of other cells ${ }^{2}$. Furthermore, NK cells produce IFN- $\gamma$ synergizing with other cells, such as dendritic cells. After the onset of the antiviral immune response, $T$ cells and $B$ cells begin their participation. In their CD8+ subpopulation, T cells contribute directly to eliminating infected cells through their TNF-tumor necrosis factor and CD95-CD95R perforin-granzyme B mediated cytotoxic activity ${ }^{3}$. Simultaneously, CD4+ $T$ cells are critical participants for $B$ cell activation, producing a cytokine pro-inflammatory environment and antibody isotype switching ${ }^{4}$. These responses contribute to the control of future viral infections. The absence of normal cellular or effector capacity influences the control of infections and reinfections.

The post-transplant immune response can be affected by multiple factors (the type of transplant, cell source, $T$ cell depletion, graft-versus-host disease [GVHD], immunosuppressive drugs, and associated infections), which favor a state of immunosuppression predisposing post-transplant patients to infections ${ }^{5,6}$.

Viral respiratory infections in pediatric patients with HSCT impact overall survival and are associated with increased morbidity and mortality. With a prevalence between 1 and $55 \%$ in pediatric patients with HSCT, viral respiratory infections are usually present with a seasonal distribution similar to that of the pediatric population, prevailing during the autumn/winter sea$\operatorname{son}^{7-9}$. Most viral respiratory infections in these patients are usually acquired in the community, with the most frequently reported agents being human rhinovirus, influenza, respiratory syncytial virus (RSV), parainfluenza, adenovirus, metapneumovirus, and coronavirus, among others. However, up to $48 \%$ of respiratory viral infections may be associated with nosocomial transmission ${ }^{10,11}$. Clinical manifestations range from mild upper airway symptoms (rhinorrhea, odynophagia, coughing, sneezing, or epiphora) to severe pneumonia with respiratory failure. The incidence of the upper respiratory tract infections (URTIs) in pediatric patients with HSCT varies depending on the viral agent: influenza A/B virus and human rhinovirus show the highest incidence (1-50\%). Lower respiratory tract infections (LRTIs) also depend on the viral agent; however, they can present an incidence from 0 to $70 \%$ at diagnosis. Between 20 and $30 \%$ of URTIs progress to LRTIs, depending on the viral agent causing the infection ${ }^{7,12}$.

Risk factors for URTI progression to LRTI in pediatric patients with HSCT are the following: GVHD, steroid use, a myeloablative conditioning regimen, the timing of infection relative to the transplant period, 
lymphopenia $(<200$ lymphocytes/ $\mu$ l), and neutropenia $(<500 \text { neutrophils/ } \mu l)^{13,14}$.

In patients undergoing HSCT, viral respiratory infections are associated with prognosis and survival. Mortality associated with viral respiratory infections is approximately $20 \%$, although some studies report up to $40 \%^{15-17}$. Other complications associated with viral respiratory infections are decreased total lung capacity $(67 \%)$, alloimmune pulmonary syndromes, idiopathic interstitial pneumonia, bronchiolitis obliterans (10.9\%), and bronchiolitis obliterans with organizing pneumonia $(16.4 \%)$. Case series where the viral respiratory infection was associated with delayed engraftment or, in the most severe cases, secondary long-term graft loss have been reported $\mathrm{d}^{7,18,19}$.

In the HSCT patient, the immune system does not generate a response similar to that of the healthy pediatric patient during a viral infection since there is a depletion of innate and adaptive immunity, together with the loss of barrier mechanisms (mucosa) secondary to the transplantation process (chemotherapy and radiotherapy). In addition to the previously mentioned factors, these alterations generate a greater predisposition to complications and death in the transplanted patient ${ }^{20-22}$. To know the frequency and evolution of viral respiratory infections and the viral agents found in patients who underwent HSCT, we reviewed the cases at the Hospital Infantil de México Federico Gómez (HIMFG).

\section{Methods}

From January 2017 to December 2019, we conducted a cross-sectional, descriptive, observational study in HSCT patients (aged 0 to 18 years) with a viral respiratory tract infection (RTIs), and viral agent isolation at the HIMFG.

\section{Patients}

We included inpatients and outpatients with HSCT presenting to the emergency department with respiratory symptoms and a positive respiratory panel, patients in the immediate post-transplant period, and patients under surveillance with a survival of more than 2 years. Furthermore, patients with clinically GVHD data and under treatment with immunosuppressive drugs were considered. We excluded patients with incomplete data on the record and no isolated viral agent in the respiratory virus panel.
We collected the following data: underlying disease, type of transplant, GVHD, immunosuppressive treatment, other treatments applied, and patient evolution. Chemotherapy and radiotherapy were used in all patients according to the underlying pathology and the indicated conditioning scheme. Furthermore, patients who had an allogeneic transplant received prophylactic treatment for GVHD. As a protocol and following international guidelines, antiviral (herpes family virus), antifungal, and antibacterial prophylaxis were used in all patients. In patients whose report was positive for a viral agent in a sample obtained from the nasopharyngeal swab, no isolation of bacterial pathogens was evidenced by other laboratory means.

\section{Definitions}

Airway infection was defined in a patient who presented respiratory symptoms during hospitalization or as an outpatient with rhinorrhea, cough, odynophagia, and nasal congestion. Viral airway infection was considered in a patient with respiratory symptoms in whom a viral agent was identified by polymerase chain reaction (PCR) test. URTI was defined in cases with respiratory symptoms and no hypoxemia or changes in chest X-ray, while LRTI in cases with respiratory symptoms and hypoxemia and changes in chest X-ray. Reinfection was classified in any patient who presented a repeated clinical event of respiratory infection, with the isolation of the viral agent. GVHD was defined and classified according to the literature ${ }^{23}$. Neutropenia was defined as neutrophils $<500$ cells $/ \mu$ l and lymphopenia as lymphocytes $<200$ cells $/ \mu$ l.

Complications assessed were the requirement for supplemental oxygen (non-rebreather mask, face tent, or nasal cannula), non-invasive mechanical ventilation, invasive mechanical ventilation, admission to the pediatric intensive care unit, and death related to RTIs.

\section{Respiratory virus panel}

Multiplex PCR was performed using low-density microarrays, employing the $\mathrm{CLART}^{\circledR}$ PneumoVir platform (Genomica), following the manufacturer's instructions for the detection of the following viruses: adenovirus, human rhinovirus, bocavirus, coronavirus, and enterovirus (echovirus), influenza A (human H3N2, human $\mathrm{H} 1 \mathrm{~N} 1$, and $\mathrm{H} 1 \mathrm{~N} 1 / 2009$ subtypes), influenza $B$, influenza $C$, human metapneumovirus (subtypes $A$ and B), parainfluenza (1, 2, 3, and 4), and RSV type A and B. Subsequently, on March 2019, 21 respiratory 
tract infectious agents were determined simultaneously by identifying nucleic acids of respiratory viruses and bacteria with labeled microspheres. The $\mathrm{NxTAG}^{\circledR}$ Respiratory Pathogen Panel (qualitative test) was used. The reaction was amplified through reverse transcription and PCR in a single step, and the resulting product was subjected to microsphere hybridization within the same reaction tube. The labeled and hybridized microspheres were then classified and read using the MAGPIX ${ }^{\circledR}$ instrument, and the signals were analyzed using SYNCTTM software. Agents detected were influenza $A$, influenza $A H 1$, influenza $A H 3$, influenza $B$, RSV (A and B), coronavirus 229E, coronavirus OC43, coronavirus NL63, coronavirus HKU1, human metapneumovirus, human rhinovirus/human enterovirus, adenovirus, parainfluenza (1, 2, 3, and 4), human bocavirus, Chlamydophila pneumoniae, Mycoplasma pneumonia, and Legionella pneumophila.

\section{Statistical analysis}

Descriptive statistics were performed reporting measures of central tendency and percentages.

\section{Results}

Fifty-four patients with HSCT were reported during the study, from which $66.6 \%(36 / 54)$ presented a clinical picture of respiratory infection in the post-transplant stage (from day 0 to 1140). Four events were excluded from the analysis because of missing data on the clinical record; thus, 32 clinical events of RTIs were reviewed. Patients with positive virus results by PCR were analyzed to avoid bias due to other infectious agents. In $62.5 \%$ (20/32) of these clinical events, the respiratory virus panel confirmed a viral etiology.

The patients' mean age was 8 years 11 months (2 years 8 months- 15 years 4 months), and 65\% (13/20) were female. The diseases present were acute lymphoblastic leukemia (10/20), acute myeloid leukemia (4/20), benign hematologic diseases (2/20), solid tumors $(2 / 20)$, and osteopetrosis (1/20). A total of $7 / 20$ haploidentical transplants (35\%), 2/20 autologous transplants (10\%), and 18/20 allogeneic transplants (90\%) were performed. The following conditioning regimens were used: myeloablative in 16/20 (80\%) and reduced intensity in $4 / 20(20 \%)$. The characteristics of the population are described in table 1.

Patients with RTIs were at different post-transplant stages (day 0-day 1140). There were 7/20 (35\%) RTI
Table 1. Characteristics of patients with hematopoietic stem cell transplantation who developed a viral respiratory infection

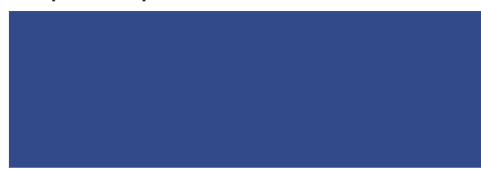

Patients with HSCT and respiratory infection of viral etiology $(n=20)$

Mean age

8 years 11 months

Gender

Male

Female

7

Underlying disease

ALL

AML

SAA

PRCA

Neuroblastoma

Retinoblastoma

Osteopetrosis

Type of transplant

Allogeneic

DR $100 \%$

DR $90 \%$

DR $75 \%$

Not related $100 \%$

Haploidentical

Autologous

13

Cell source

Bone marrow

Peripheral blood

Conditioning regimen

Myeloablative

Reduced-intensity

16

Type of infection

URTI

$30 \%$

LRTI

$70 \%$

Progression

$10 \%$

Symptoms

Rhinorrhea $\quad 25 \%$

$\begin{array}{ll}\text { Cough } & 25 \% \\ & 40.6 \%\end{array}$

Crackles $\quad 18.7 \%$

\begin{tabular}{l|l} 
Respiratory distress & $50 \%$
\end{tabular}

Fever $\quad 31.2 \%$

Low oxygen saturation or hypoxemia $\quad 46.8 \%$

$\begin{array}{ll}\text { Odynophagia } & 15.6 \%\end{array}$

\begin{tabular}{l|l} 
Changes in imaging studies & $46.8 \%$
\end{tabular}

Results of blood analysis

Lymphopenia $(<200$ cells $/ \mu l) \quad 6.2 \%$

Neutropenia $(<500$ cells/ $\mu$ l) $\quad 9.3 \%$

Complications

Supplemental oxygen requirement $\quad 65.6 \%$

$\begin{array}{ll}\text { Mechanical ventilation } & 18.7 \%\end{array}$

Intensive care unit $\quad 12.5 \%$

$\begin{array}{ll}\text { Death } & 6.2 \%\end{array}$ 
Table 1. Characteristics of patients with hematopoietic stem cell transplantation who developed a viral respiratory infection (Continued)

\begin{tabular}{|l|c|}
\hline & $\begin{array}{c}\text { Patients with HSCT } \\
\text { and respiratory } \\
\text { infection of viral } \\
\text { etiology }(\mathbf{n}=\mathbf{2 0})\end{array}$ \\
\hline Treatment & \\
Antibiotic & $80 \%$ \\
Antiviral & $15 \%$ \\
Symptomatic/surveillance & $5 \%$
\end{tabular}

ALL: acute lymphoblastic leukemia; AML: acute myeloid leukemia; HSCT: hematopoietic stem-cell transplantation; LRTI: lower respiratory tract infection; PRCA: pure red cell aplasia; SAA: severe aplastic anemia; URTI: upper respiratory tract infection.

Table 2. Respiratory viruses detected in patients with respiratory symptomatology

\begin{tabular}{|l|c|}
\hline Virus isolated & n (\%) \\
\hline Adenovirus & $4(14.8)$ \\
\hline Influenza & $7(25.9)$ \\
\hline Influenza A & $2(7.4)$ \\
Influenza A H1N1 & $1(3.7)$ \\
Influenza A H3N2 & $2(7.4)$ \\
\hline Influenza B & $2(7.4)$ \\
\hline Metapneumovirus B & $4(14.8)$ \\
\hline Parainfluenza 3 & $2(7.4)$ \\
\hline Rhinovirus & $5(18.5)$ \\
\hline Respiratory syncytial virus & $5(18.5)$ \\
Respiratory syncytial virus A & $4(14.8)$ \\
\hline Respiratory syncytial virus B & $1(3.7)$ \\
\hline Total viruses isolated & $27(100)$ \\
\hline
\end{tabular}

events during the first 100 days post-transplant, $3 / 20$ (15\%) between 100 and 365 days post-transplant, and 9/20 $(45 \%)$ after 365 days post-transplant. Only $2 / 20(10 \%)$ of RTIs occurred in the first 30 days post-HSCT.

A total of 27 viruses were identified (Table 2). In URTI, the most frequent viruses were adenovirus, influenza $\mathrm{A} / \mathrm{B}$, and metapneumovirus, while in LRTI, influenza, RSV, and human rhinovirus (Table 3). Viral co-infections were identified in $36.8 \%$ of the viral infections $(7 / 19)$, the most frequent being influenza $A$-metapneumovirus $B$ in two cases. Other co-infections were influenza $A$-human rhinovirus, influenza B-metapneumovirus $B$, influenza $A$ H3N2-metapneumovirus $B$, human rhinovirus-metapneumovirus $B, R S V B$-adenovirus, and one case of three viral agents' co-infection: RSV A-human rhinovirus-adenovirus. A significant seasonal distribution was observed
Table 3. Respiratory viruses isolated according to the clinical presentation

\begin{tabular}{|l|c|}
\hline & Isolated agents n (\%) \\
\hline URTI & $8(29.6)$ \\
\hline Adenovirus & 2 \\
\hline Parainfluenza & 1 \\
\hline Influenza & 2 \\
\hline Influenza A & 1 \\
\hline Influenza B & 1 \\
\hline Metapneumovirus B & 2 \\
\hline Human rhinovirus/enterovirus & 1 \\
\hline LRTI & $19(70.3)$ \\
\hline Adenovirus & 2 \\
\hline Parainfluenza & 1 \\
\hline Influenza & 5 \\
\hline Influenza A & 1 \\
\hline Influenza A H3N2 & 2 \\
\hline Influenza A H1N1 & 1 \\
\hline Influenza B & 1 \\
\hline RSV & 5 \\
\hline RSV A & 4 \\
\hline RSV B & 1 \\
\hline Metapneumovirus B & 2 \\
\hline Human rhinovirus & 4 \\
\hline Total isolated agents & $2700)$ \\
\hline
\end{tabular}

LRTI: lower respiratory tract infection; RSV: respiratory syncytial virus; URTI: upper respiratory tract infection.

in the fall/winter season (15/19 events; $78.9 \%)$ in comparison to spring/summer (4/19 events; 21\%) (Fig. 1).

Clinically, $31 \%$ of patients (6/20) showed URTI symptoms, and $15 \%(3 / 20)$ progressed to LRTI. A complication was observed in $83.3 \%$ of patients $(5 / 6)$ in the URTI group. Furthermore, $65 \%$ of patients (13/20) showed LRTI symptoms, and all had at least one complication. In $52.6 \%$ of the chest $X$-rays, variable images ranging from mild interstitial infiltrate to consolidation were identified.

Regarding treatment, $84 \%$ of the patients were administered with empirical broad-spectrum antibiotics (cefepime, meropenem, and vancomycin) before identifying the viral agent. Management with an antiviral (oseltamivir) was initiated in $21 \%$ of the patients, and only supportive and symptomatic management in 5\%.

Regarding complications, supplemental oxygen was the most frequently used in $70 \%$ of the events (nasal 


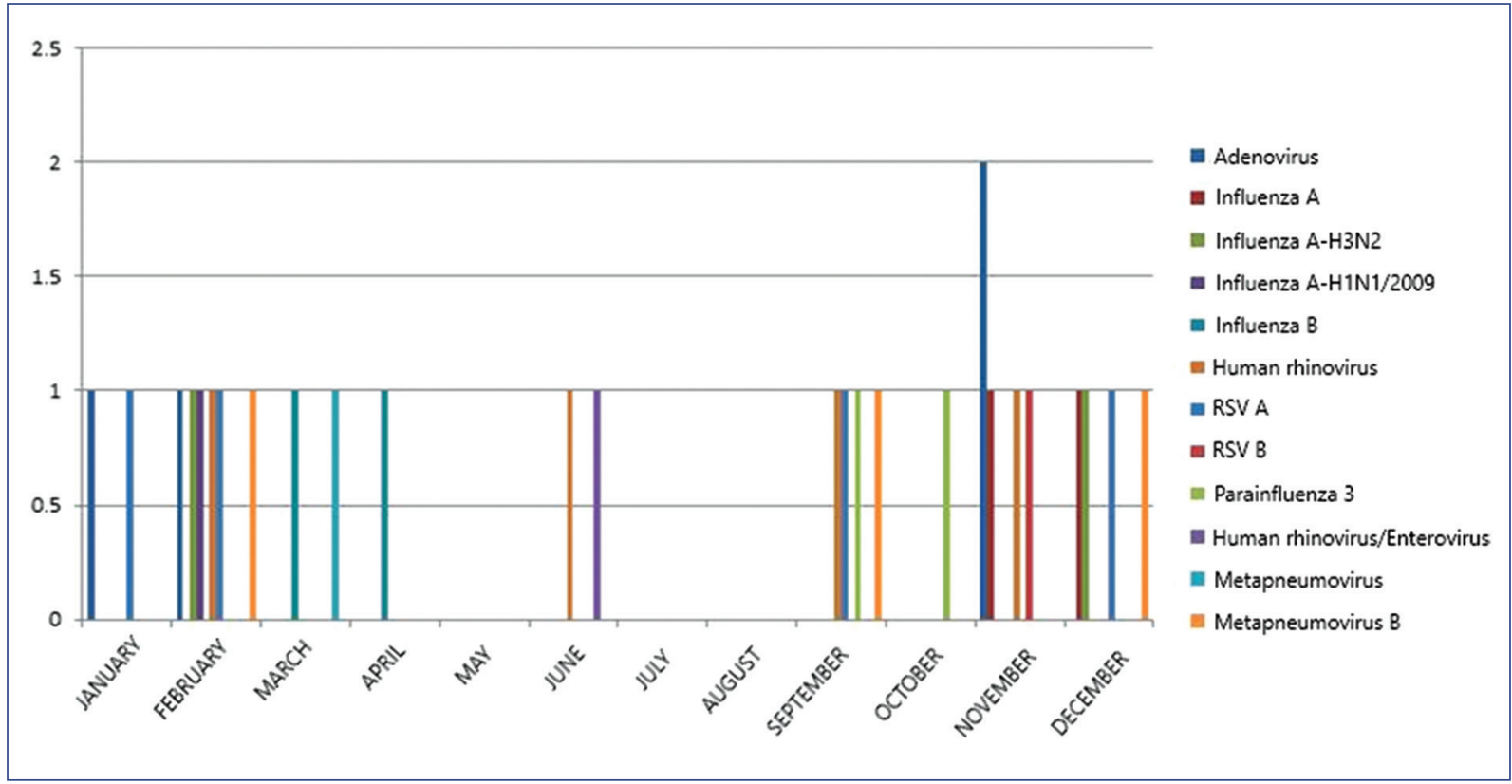

Figure 1. Seasonal distribution of viruses in hematopoietic stem cell transplant patients. RSV: respiratory syncytial virus.

prongs [2/20] or non-rebreathing mask [12/20]), followed by mechanical ventilation support (non-invasive [2/20] or invasive [2/20]), which was required in $20 \%$ of the events. Furthermore, $15.7 \%$ of the events required management in a pediatric intensive care unit. Mortality of $10.5 \%$ was associated with RTIs, isolating RSV A in one patient and influenza A- metapneumovirus $B$ in another patient.

\section{Discussion}

According to our results, community-acquired viral respiratory infections are frequent infectious events in post-transplant patients. Literature has reported a predominance of viral respiratory infections in non-transplanted patients < 5 years old; however, we did not observe an age-related predominance of viral respiratory infections in this group of patients. It is necessary to consider that HSCT favors the immunosuppressive state of patients at any age ${ }^{12,24}$.

Furthermore, we detected a viral RTIs in $25.9 \%$ of the HSCT patients (14/54) during the post-transplant stage, and $52 \%$ of the events occurred in the first year post-transplant. Different studies have shown higher frequencies of infection and risk of complications in the first year post-transplant ${ }^{25-27}$. Our sample of HSCT patients behaved similarly to other literature reports since respiratory viral infections can occur in any HSCT patient, even with different underlying diagnoses (oncologic or hematologic, and benign or malignant), different conditioning regimens, types of transplant, and cell sources.

Notably, only two patients showed respiratory infections during the period in which they were in the HSCT unit (first 30 days after transplantation). During this period, they have more extraordinary protection measures. Health-care personnel (medical, nursing, cleaning, and maintenance personnel) at the hospital and family members accompanying the patient should be considered a source of infection. Respiratory infections after 100 days post-transplant occurred in a significant percentage of patients $(63 \%)$. Considering that they are under ambulatory follow-up and in contact with community agents, it is necessary to be aware of multiple risk factors for viral respiratory infections, such as myeloablative conditioning regimen, immune reconstitution, GVHD activity, use of immunosuppressive treatment, and preventive measures (vaccines) ${ }^{27-29}$.

A highly variable frequency of respiratory viral infections $(5-46 \%)$ has been described in the literature, depending on the respiratory virus isolated. The frequency of presentation in the population included in this study is in line with other reports, suggesting that viruses are an important part of the etiological agents of respiratory infections in post-transplant patients $s^{7,29,30}$. The seasonal distribution of viral agents found in 


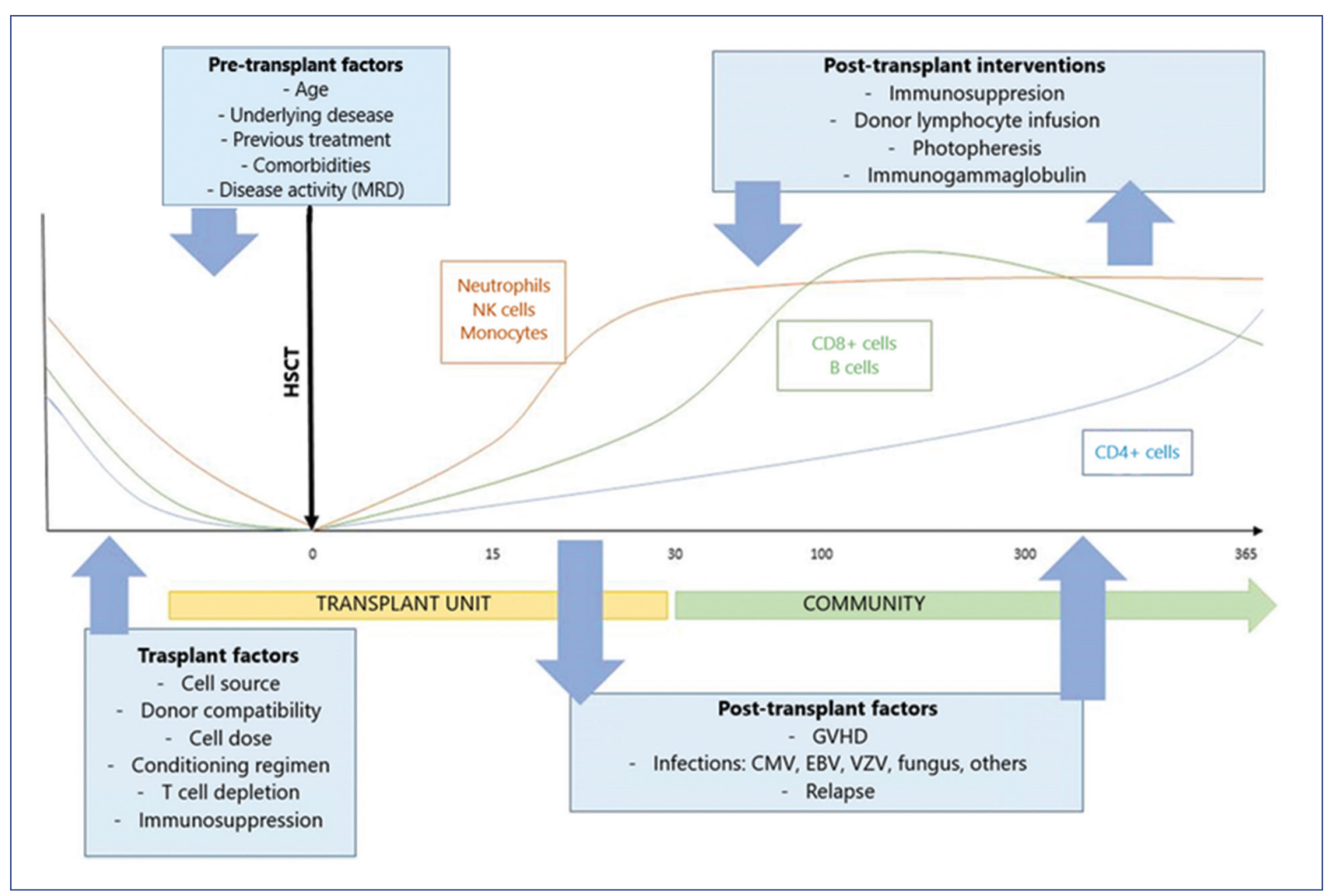

Figure 2. Factors involved and expected immune reconstitution in the hematopoietic stem cell transplant patient. CMV: cytomegalovirus; EBV: Epstein Barr virus; GVHD: graft-versus-host disease; MRD: minimal residual disease; NK: natural killer cells; VZV: varicella-zoster virus.

patients who underwent HSCT was similar to the seasonal distribution of viruses in other pediatric patients at the Hospital Infantil de México Federico Gómez. In a study conducted by Ison and Hirsch in 2019, it is mentioned that the most frequently identified viral agents in patients with HSCT were human rhinovirus, RSV, and influenza, which present a similar seasonality to that of the community, being more frequent in autumn and winter ${ }^{31}$.

Soudani et al. conducted a study of the prevalence of acute respiratory infections in patients with cancer and HSCT, demonstrating a higher incidence of respiratory infections, in addition to co-infections with multiple viruses ${ }^{9}$. In our patients, we found a high frequency $(36.8 \%)$ of viral co-infections; additionally, three patients had recurrent reinfections. This high frequency observed in our study may be due to multiple factors such as GVHD (present in 14/20) or immunosuppressant use (15/20), among others. When dealing with patients with HSCT, it is necessary to consider that respiratory infections with community viral agents are facilitated. Due to a compromised immune system, these patients may present reinfections with the same viral agent and, occasionally, co-infections.

One of the limitations of this study is that we did not correlate risk factors with the presentation of RTIs.

More LRTI than URTI were found $(70 \%$ vs. $30 \%$, respectively), with a progression from upper to lower clinical presentation. In Korea, in 2013, Choi et al. studied 175 pediatric transplant patients who had 89 clinical episodes of viral respiratory infections: about $61.8 \%$ of the infections were in upper airways, $38.2 \%$ in lower airways, and mortality was associated with viral infections in $3.3 \%(3 / 89)^{32}$. We consider that our patients' immunosuppression state favored the presentation of severe clinical pictures and a tendency to complications.

Since these patients were immunocompromised empirical antibiotic coverage was initiated in $80 \%$ of the patients as part of the initial management of respiratory infections. However, after identifying the viral agent responsible for the respiratory symptoms, directed 
treatment was given in $20 \%$ of the patients. Management with neuraminidase inhibitors was initiated in patients in whom influenza $A / B$ was detected; $5 \%$ of the patients received treatment for general symptoms. In our patients, treatment with antiviral agents was only given to those who presented influenza. However, it has been described that the use of inhaled ribavirin as a treatment for RSV infections in patients with HSCT reduced viral load, invasive mechanical ventilation, and hospital stay $^{15,27}$.

Complications occurred in $90 \%$ of patients, the most frequent being the requirement of supplemental oxygen (70\%). Two patients died in association with the viral respiratory infection: the first patient required HSCT due to pure red cell aplasia and had three clinical events of respiratory infections 100 days post-transplant, with different viral agents isolated in each infection. In the last infectious event, the patient presented a co-infection with influenza $A$ and metapneumovirus $B$, which contributed to respiratory failure, requiring support with assisted mechanical ventilation, and progressing to severe pulmonary damage. The second patient required an HSCT for acute myeloid leukemia and died secondary to a respiratory failure event with the isolation of influenza A H1N1; besides, she presented septic shock data. Although no other pathogenic agent was isolated as the septic shock etiology, we cannot rule out its participation. Mortality associated with viral respiratory infections in pediatric patients with HSCT is highly variable. Some studies reported that it is $3 \%$ and as high as $70 \%$ in other studies. This frequency of presentation is associated with multiple characteristics: the identified viral agent, time of presentation of the infection regarding the transplant, type of transplant performed, conditioning regimen used, presence of GVHD, immunosuppressants (steroids), and chronic complications ${ }^{25,28}$. We consider that one explanation for this response is the late immune reconstitution of hematopoietic progenitor cell transplantation (Fig. 2). In the study conducted by Parra et al., it was reported that patients with HSCT achieve a late immune reconstitution, having an adequate cellular number up to 2 years after transplantation; however, no association with a more significant number of infections was observed ${ }^{33}$.

Viral respiratory infections are frequent in pediatric patients with HSCT (62.5\%) and occur throughout the year. The most frequent viruses were human rhinovirus, RSV, and influenza. As these infections have an essential impact on morbidity and mortality, efforts should be made to establish strategies for their prevention, identification, and timely supportive management.

\section{Ethical disclosures}

Protection of human and animal subjects. The authors declare that no experiments were performed on humans or animals for this study.

Confidentiality of data. The authors declare that they have followed the protocols of their work center on the publication of patient data.

Right to privacy and informed consent. The authors have obtained the written informed consent of the patients or subjects mentioned in the article. The corresponding author has this document.

\section{Conflicts of interest}

The authors declare no conflict of interest.

\section{Funding}

None.

\section{References}

1. de Koning C, Plantinga M, Besseling P, Boelens JJ, Nierkens S. Immune reconstitution after allogeneic hematopoietic cell transplantation in children. Biol Blood Marrow Transplant. 2016;22:195-206.

2. Honda K, Yanai H, Takaoka A, Taniguchi T. Regulation of the Type I IFN induction: a current view. Int Immunol. 2005;17:1367-78.

3. Kulinski JM, Tarakanova VL, Verbsky J. Regulation of antiviral CD8 T-cell responses. Crit Rev Immunol. 2013;33:477-88.

4. Chen CC, Koenig A, Saison C, Dahdal S, Rigault G, Barba T, et al. CD4+ $T$ cell help is mandatory for naive and memory donor-specific antibody responses: impact of therapeutic immunosuppression. Front Immunol. 2018;9:1-14.

5. van der Maas NG, Berghuis D, van der Burg M, Lankester AC. B Cell reconstitution and influencing factors after hematopoietic stem cell transplantation in children. Front Immunol. 2019;10:1-8

6. Bae KW, Kim BE, Koh KN, Im HJ, Seo JJ. Factors influencing lymphocyte reconstitution after allogeneic hematopoietic stem cell transplantation in children. Korean J Hematol. 2012;47:44-52

7. Versluys $A B$, Boelens $\mathrm{JJ}$. Morbidity and mortality associated with respiratory virus infections in allogeneic hematopoietic cell transplant: too little defense or harmful immunity? Front Microbiol. 2018;9:1-7.

8. Vliora C, Papadakis V, Doganis D, Tourkantoni N, Paisiou A, Kottaridi C, et al. A prospective study on the epidemiology and clinical significance of viral respiratory infections among pediatric oncology patients. Pediatr Hematol Oncol. 2019;36:173-186.

9. Soudani N, Caniza MA, Assaf-Casals A, Shaker R, Lteif M, Su Y, et al. Prevalence and characteristics of acute respiratory virus infections in pediatric cancer patients. J Med Virol. 2019;91:1191-1201.

10. Abbas S, Raybould JE, Sastry S, de la Cruz O. Respiratory viruses in transplant recipients: more than just a cold. Clinical syndromes and infection prevention principles. Int J Infect Dis. 2017;62:86-93.

11. Lo MS, Lee GM, Gunawardane N, Burchett SK, Lachenauer CS, Lehmann LE. The impact of RSV, adenovirus, influenza, and parainfluenza infection in pediatric patients receiving stem cell transplant, solid organ transplant, or cancer chemotherapy. Pediatr Transplant. 2013;17:133-43.

12. Pochon C, Voigt S. Respiratory virus infections in hematopoietic cell transplant recipients. Front Microbiol. 2019;9:1-17.

13. Hijano DR, Maron G, Hayden RT. Respiratory viral infections in patients with cancer or undergoing hematopoietic cell transplant. Front Microbiol. 2018;9:1-19.

14. Shah DP, Ghantoji SS, Ariza-Heredia EJ, Shah JN, El Taoum KK, Shah PK, et al. Immunodeficiency scoring index to predict poor outcomes in hematopoietic cell transplant recipients with RSV infections. Blood. 2014;123:3263-8.

15. Khawaja F, Chemaly RF. Respiratory syncytial virus in hematopoietic cell transplant recipients and patients with hematologic malignancies. Haematologica. 2019;104:1322-31. 


\section{J.F. Gaytán-Morales, et al.: Respiratory infections in stem cell transplantation}

16. Ljungman $\mathrm{P}$. Respiratory virus infections in stem cell transplant patients: the European experience. Biol Blood Marrow Transplant. 2001;7:5S-7S.

17. Rivadeneyra P. Factores Asociados a Complicaciones Infecciosas en Pacientes Pediátricos con Trasplante de Células Progenitoras Hematopoyéticas. Ciudad de México: Hospital Infantil de México Federico Gómez-UNAM, México. Tesis de Posgrado; 2019.

18. Versluys $A B$, Rossen JW, van Ewijk B, Schuurman R, Bierings MB, Boelens JJ. Strong association between respiratory viral infection early after hematopoietic stem cell transplantation and the development of life-threatening acute and chronic alloimmune lung syndromes. Biol Blood Marrow Transplant. 2010;16:782-91.

19. McCarthy AJ, Kingman HM, Kelly C, Taylor GS, Caul EO, Grier D, et al. The outcome of 26 patients with respiratory syncytial virus infection following allogeneic stem cell transplantation. Bone Marrow Transplant. 1999;24:1315-22.

20. Lewin SR, Heller G, Zhang L, Rodrigues E, Skulsky E, van de Brink MR et al. Direct evidence for new T-cell generation by patients after either T-cell-depleted or unmodified allogeneic hematopoietic stem cell transplantations. Blood. 2002;100:2235-42.

21. Novitzky N, Davison GM. Immune reconstitution following hematopoietic stem-cell transplantation. Cytotherapy. 2001;3:211-20.

22. Tomblyn M, Chiller T, Einsele H, Gress R, Sepkowitz K, Wingard JR, et al. Guidelines for preventing infectious complications among hematopoietic cell transplantation recipients: a global perspective. Biol Blood Marrow Transplant. 2009;15:1143-238.

23. Ferrara J, Antin J. The pathophysiology of graft-versus-host disease. In Forman S, Negrin R, editors. Thomas' Hematopoietic Cell Transplantation: stem Cell Transplantation. West Sussex: Wiley Blackwell; 2015. p. 146-55

24. Weigt SS, Gregson AL, Deng JC, Lynch JP $3^{\text {rd }}$, Belperio JA. Respiratory viral infections in hematopoietic stem cell and solid organ transplant recipients. Semin Respir Crit Care Med. 2011;32:471-93.
25. Hutspardol S, Essa M, Richardson S, Schechter T, Ali M, Krueger J, et al. Significant transplantation-related mortality from respiratory virus infections within the first one hundred days in children after hematopoietic stem cell transplantation. Biol Blood Marrow Transplant. 2015;21:1802-7.

26. Fontana L, Strasfeld L. Respiratory virus infections of the stem cell transplant recipient and the hematologic malignancy patient. Infect Dis Clin North Am. 2019;33:523-44.

27. Piñana JL, Pérez A, Montoro J, Hernani R, Lorenzo I, Giménez E, et al. The effect of timing on community-acquired respiratory virus infection mortality during the first year after allogeneic hematopoietic stem cell transplantation: a prospective epidemiological survey. Bone Marrow Transplant. 2020;55:431-40.

28. Renaud C, Xie H, Seo S, Kuypers J, Cent A, Corey L, et al. Mortality rates of human metapneumovirus and respiratory syncytial virus lower respiratory tract infections in hematopoietic cell transplantation recipients. Biol Blood Marrow Transplant. 2013;19:1220-6.

29. Paulsen GC, Danziger-Isakov L. Respiratory viral infections in solid organ and hematopoietic stem cell transplantation. Clin Chest Med. 2017;38:707-26

30. García-Castillo C, Olaya-Vargas A, Pérez-García M, Melchor-Vidal YB, Cardoso-Yah G, Torres-Alarcón CG. Procesos infecciosos en el trasplante de células progenitoras hematopoyéticas. Rev Hematol Mex. 2020; 21:41-50.

31. Ison MG, Hirsch HH. Community-acquired respiratory viruses in transplant patients: diversity, impact, unmet clinical needs. Clin Microbiol Rev. 2019;32:1-32

32. Choi JH, Choi EH, Kang HJ, Park KD, Park SS, Shin HY, et al. Respiratory viral infections after hematopoietic stem cell transplantation in children. J Korean Med Sci. 2013;28:36-41.

33. Parra-Ortega I, Nájera-Martínez N, Gaytán-Morales F, Castorena-Villa I, Cortés-Flores C, López-Martínez B, et al. Reconstitución de células NK posterior al trasplante de células progenitoras hematopoyéticas (TCPH) en pacientes pediátricos. Gac Med Mex. 2020;156:188-94. 